\title{
Factors Affecting Hedonic Brand Loyalty on the Fine Dining Indonesian Food Restaurant in Jakarta
}

\author{
Linda Desafitri R.B, Farida Jasfar, Hamdy Hady \\ willy.arafah@gmail.com
}

Abstract: This study examined the influence of the Factors Affecting Hedonic Brand Loyalty in Restaurant Fine Dining Indonesian Food in Jakarta. Respondents from this study were luxury consumers of Indonesian-style food restaurants that already come twice or more at the restaurant. There were 340 samples used in this study. The samplingtechniquethat used in this study used Purposive Sampling which was distributed to 10 predetermined luxury restaurants. Tests for validity and reliability were conducted to test the questionnaire instruments used. There were eleven hypotheses tested in this study. The analysis technique that used in testing the hypothesis is the (Structural Equation Model-SEM) and the LISREL 8.80 for Goodness of Fit Test.

Some research results show that Food Quality has a negative and significant effect on Emotion, for service quality result has a positive and significant effect on emotion, Food Quality, Service Quality, Atmospherics and Product Knowledge contribute simultaneously positively and significantly to emotions and food quality, service quality, atmospherics, product knowledge and emotions contribute simultaneously to have a positive and significant effect on Brand Loyalty.

The theoretical implications of this study reveal additional empirical findings, including Food Quality, Service Quality, Atmospherics and Product Knowledge contributing simultaneously a positive and significant effect on Emotions and Food Quality, Service Quality, Atmospherics, Product Knowledge and Emotions contributing simultaneously positive and significant effects on Brand Loyalty. The managerial implications of this study in the context of luxury restaurants service quality are the dominant variable that influences consumer emotions and Brand Loyalty, so that the employees must be improved and considered by creating reliable employees who provide overall service quality. To be able to build emotions as well as loyalty to the restaurant.

Keywords: Atmospherics, Brand Loyalty, Emotions, fine dining restaurant Food Quality, Product Knowledge and Service Quality.

\section{INTRODUCTION}

Consumers experience of various emotions, simultaneously or successively when interacting with the service providers (Maguire \& Geiger, 2015). Recently the findings of Bilgihan et al. (2016) consider the key of the emotional role in services and emphasizes that in the context of service companies have to pay more attentions to the consumer's emotions to increase the loyalty $\mathrm{df}$ customers. The role and effects of emotions attract more attention from the marketing intellectuals in Indonesia in their search for a better understanding of consumers and the consumption experience (Mattila and Enz, 2002; Ladhari, 2007).

Special attentions have also been given to the concept of brand loyalty (Bowen \& Mc,Cain, 2015) because it can trigger profits for a company (Kandampully et al., 2015). Although several studies have been conducted to examine the relationship of loyalty and service quality only a little attention has been given to the role of emotions in this relationship (Han \& Jeong, 2013). Brunner Sperdinet al., 2012; Su et al., 2015 and Tsai, 2014 noted the emotional role of consumers during the service experience received little attention despite its undoubtedly important role. To overcome this gap several efforts have been made recently to combine emotional elements in the relationship of loyalty, service quality and emotion to be able to deepen understanding of concepts (Jani\& 
Han, 2015; Han \&Jeong, 2013; Lin \& Liang, 2011; Namkung \& Jang, 2010). A person can have positive hedonic emotions such as pleasure, joy and excitement as well as negative hedonic emotions such as frustration, sadness and disappointment.

According to Annie et al (2014) the operation of luxury restaurant, luxury restaurants in the following criteria: (1) A full-service restaurant that serves a main food menu with an average price above US \$30; (2) the average total consumer expenditure set is above US \$ 67 (excluding service and tips); (3) Restaurants are located in a five-star international hotel chain (e.g. Hilton and Hyatt Regency). Nevertheless, the notion of luxury restaurants can be continued in three ways, namely (1) Some researchers have highlighted the importance of consumer behavior in examining the emotional antecedents of diners (Han et al., 2009; Jang and Namkung, 2009; King and Meiselman, 2010) because the impact of stimuli on visitors is often intense and direct. In addition, visitor's emotions often determine their future behavioral intentions to revisit restaurants again (Jang and Namkung, 2009); (2) Research of Ryu et al. (2012) not considering the influence of other visitors as shown by Wu and Liang (2009) that other visitors' experiences can influence other consumers to eat fancy restaurants. (3) Some variables can moderate customer decision-making processes, such as expectations (Devlin et al., 2002; Wong and Dioko, 2013); however, the framework of Ryu et al. (2012) does not consider the potential moderating effects of the consumption behavior variables of restaurant visitors.

Research conducted by Norman and Annie (2015) concluded that food quality, service quality and atmosphere affect the emotion of consumers which can further influence brand loyalty in a luxury restaurant, in addition, product knowledge is a moderate variable that influences emotions (emotion) and brand loyalty (research loyalty) and this research is a follow-up study conducted by Norman and Annie (2015) who examine food quality (food quality), service quality and atmosphere affect the emotion of consumers which can then influence brand loyalty in a fancy restaurant and product knowledge is changed as independent variables rather than moderate variables such as Previous research and research will be carried out partial and simultaneous spirits between independent variables on the dependent variables.

\section{LITERATURE REVIEW}

\section{Food Quality}

Food quality is understood as a multidimensional concept, but there is no agreement on the dimensions of the individuals who shape it. Grunert et al. (1996) argue that food is classified as quality into four dimensions: hedonic (i.e. taste \&smell), health (i.e. nutritional value) comfort (i.e. time \& effort), and process (eg production process); Namkung and Jang (2008) suggest five dimensions: presentation, variation, healthy choices, taste, freshness, and temperature. Many studies have revealed food quality as a restaurant's core competency (i.e.Ha and Jang, 2010; Namkung and Jang, 2008). Grunert (2005) food quality model states that consumers evaluate food quality not only based on actual food consumption, but also on expectations food produced with information collected before consumption.

\section{Service Quality}

Service quality and customer satisfaction is the most priority marketing because they are a prerequisite for consumer loyalty such as repeat sales and positive marketing of positive word of mouth (Liu and Jang, 2009b \&Han and Ryu, 2009). In today's competitive market it is generally assumed that the key to gaining profit lies in providing high quality services which in turn will bring satisfied consumers (Han and Ryu, 2007). In particular, in the restaurant industry, consumers generally use food, the physical environment, and employee services as key restaurant experience components in evaluating the quality of restaurant services (Chow et al., 2007; Namkung and Jang, 2008; Ryu and Han, 2010).

Some studies show that food, physical environment, and employee services must function as a vital component of restaurant experience in forming perceptionsabout service quality in the restaurant industry (Ryu and Han, 2010;Jang and Namkung, 2009; Namkung and Jang, 2008;). Chow et al. (2007) examined the relationship 
between service quality, consumer satisfaction, and the frequency of consumers in the context of a full service restaurant. They capture three dimensions of service quality (i.e. Quality of interaction, physical quality, quality of results). Namkung and Jang (2008) also conducted a study to identify the key attributes of quality that significantly differentiate highly satisfied consumers from those with high personalities. Consumers who are satisfied using the context of middle to upper scale restaurants. They use three quality factors (food, atmosphere, and service) to measure the quality of consumer perceptions related to restaurant experience.

\section{Atmospherics (Physical Environment)}

Some previous studies found that the perceived quality of the physical environment (Baker et al., 1994; Nguyen and Leblanc, 2002) or the quality of services (Lai et al., 2009) can have a significant influence on the image of shops, restaurants or companies. This description can have further influence on the perceived value and satisfaction of consumers, which in turn affects their loyalty (Lai et al., 2009; Patterson and Spreng, 1997; Prendergast and Man, 2002; Ryu et al., 2008).

According to Berman \& Evans (2010: 508-509) atmospherics is a physical characteristic that is very important in creating a comfortable atmosphere for consumers who are in the store and can indirectly affect the consumer's image and buying behavior and the elements consist of (1) Exterior Has a strong influence on the image of the store, so it must be planned as well as possible. This exterior combination can make the outside of the store look unique, attractive, prominent and invite people to enter the store. Exterior consists of: Storefront, Marquee, Entrance, Dispay Windows, Exterior of thr Building Height, Sorroundingthe Stores and the Area, Parking Facilities, (2) General Interior Is planning, arranging and designing interior spaces in buildings. General interior consists of: Flooring, Color and Lighting, Scent and sound, Store Fixtures, Wall Textures, Temperature, Aisle Space, Dressing Facilities, Vertical Transportation, Store Personnel, Technology, Cleanliness, (3) Store Layout A plan to determine a specific location and arrangements for equipment, merchandise, shop aisles and shop facilities. In designing store layouts, it is necessary to note the following: Allocation of the Floor Space, Selling Space, Merchandise Space, Personnel Space, Customer Space, Classification of Store Offerings, Determination of A Traffic-Flow Pattern, Determination of Space Needs, Mapping Out in Store Locations, Arrangement of Individual Products and (4) Interior Displays It is every provision of information to consumers to influence the atmosphere of the store environment. Interior displays include: Assortment displays, Theme-setting displays, Ensemble displays, Rack displays, Cut cases.

\section{Product Knowledge}

Wang (2001) summarizes more much of the literature and reports that indices used to measure product knowledge by scientists include: (1) Consumer perceptions of how much he knows (Park and Lessig, 1981). (2) The number, type and organization of what consumers have stored in their memories (Johnson and Russo, 1984). (3)the amount of purchasing and usage experience (Marksdan Olson, 1981). Rudell (1979) uses scoresexamination to measure objective knowledge and apply self-evaluation inventory to be measured subjective knowledge. Lin and Zhen (2005) adopted the product's definition of knowledge proposed by Brucks (1984) to measure product knowledge which states that the knowledge of the product depends on consumer awareness about the product, consumer trust in it. Based on the definition of Brucks (1984) about product knowledge is divided into three(3) major categories, namely: (1) Knowledge of the subject or perceived knowledge; (2) Objective knowledge; and (3) knowledge-based experience.Zhu (2004) states that in a study when consumers choose products they usually rely on their product knowledge to evaluate and product knowledge will also affect procedures, attitudes, quantity of information search for them, then the level of product knowledge will determine the consumer purchasing decisions and indirectly affect the intention of shopping .

\section{Hedonic Emotions}

Consumers seek various values in restaurants such as social interaction, pleasure, taste, efficiency and economic reasonsPark (2004). In general, existing research shows that consumption of fast service is utilitarian while 
for dining in restaurant, luxury restaurants are emotionally hedonic (Ha and Jang, 2010, 2013; Ryu and Han, 2011; Ryu and Jang, 2007; Ryu et al., 2010). Chaudhuri and Holbrook (2001, p. 82) define that brand influence positive emotional responses to consumers as a result of their use. Consumer satisfaction and the purchase intention are directly influenced by the positive influences (Oliver, 1997). Emotional response stimulated by the physical environment or employee behavior influences various consumer outcomes, including the willingness of buyers to shop and spend their time (Nisco and Warnaby, 2014). (Jani and Han, 2015) review the intention to buy more so that it will increase in the future, recommend restaurants to others (Jang and Namkung, 2009), unplanned expenses (Nisco and Warnaby, 2014) and loyalty (Jani and Han, 2015).

\section{Brand Loyalty (Brand Loyalty)}

Consumer loyalty is a dynamic concept that is developed by strengthening commitment and trusting with partners. Such a relational loyalty approach consists of predicting future consumer behavior (Fallahi and Nameghi, 2013). Loyalty is an important aspect,especially when incidences occur which can cause divisions in relations between the two parties (Guillard and Roux, 2014; Kwang-Ho andKim, 2011). When this happens,we are able to determine the strength of the relationship that exists between consumers and brands (Ben Khelil and Bouslama, 2013). Some researchers have studied the nature and loyalty of behaviors that often also have a positive effect on the purchase of a brand (i.e. the intention to continue the relationship, help market and monitor prices) Cristau, 2003; Gurviez, 1999; Maxham and Netemeyer, 2002). Two approaches to building brand loyalty include behavioral approaches and attitude approaches. The behavioral approach refers to repeated purchases of special brands, while the attitude, approach refers to a positive attitude towards brands (Quester and Lim, 2003).

Consumers prefer brand restaurants that provide positive emotional states through symbolic elements such as conformity, brand identification or brand influence. Positive service experiences such as restaurants lead to the intention to return consumers (Lee and Cunningham, 2001; Harris and Ezeh, 2008) and willingness to recommend brands (Paswan et al., 2007). As a restaurant industry has the characteristics of intangible variables, namely emotional and psychological processes to shape brand loyalty. Attitude loyalty is a symbolic consequence of consumption in restaurants. Brand loyalty is widely recognized in the literature of the concept in brand loyalty are two dimensional construction that contains aspects of attitude and behavior (Hwang and Kandampully, 2012).

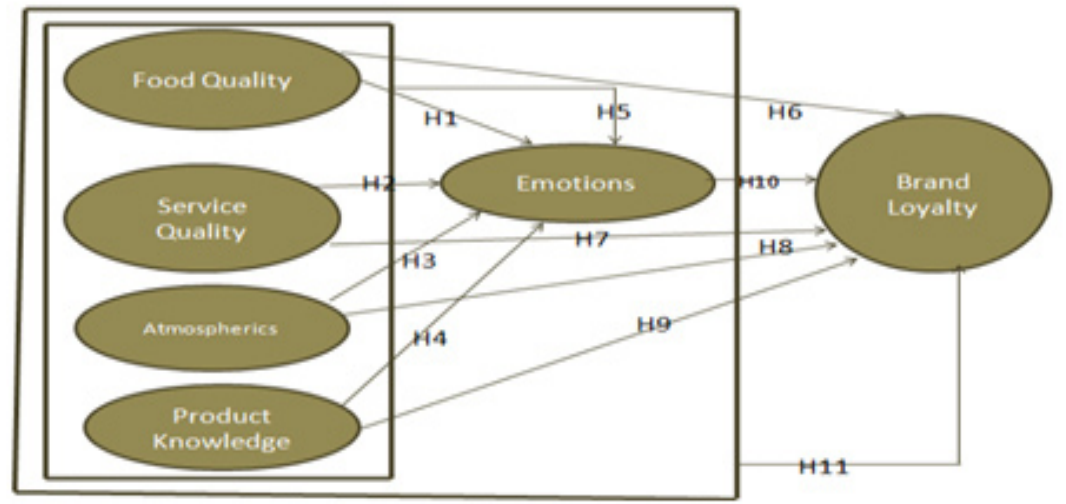

Fig1. Conceptual Framework

\section{RESEARCH HYPOTHESIS}

\section{Effect of Food Quality on Emotions}

Food quality, for example the quality of food and beverages can affect consumer emotions (Norman \& Annie, 2015). Kwun and Oh (2006) define food and beverages as the core of restaurant products. Freshness and taste of food can significantly impact consumer emotions. In addition, Wu and Liang (2009) note that serving food 
and drinks is an important part of the quality and quality of a luxury restaurant. Affect consumer emotions. Based on previous literature findings (i.e.Kwun and Oh, 2006; Wu and Liang, 2009), this study hypothesizes the following:

\section{H1: There is an influence between Food Quality and Emotion}

\section{Influence between Service Quality on Emotions}

In the context of serving food to consumers, restaurant employees interact directly with consumers during their visits (Jang and Namkung, 2009; Kwun and Oh, 2006; Wu and Liang, 2009. In a restaurant, employee knowledge of restaurants and menus, their level of help and are they reliable or not,often considered from previous literature has confirmed that staff service quality influences consumer emotions (i.eJangdanNamkung, 2009; Kwun and Oh, 2006) therefore:

\section{H2: There is an influence between Service Quality on Emotions}

\section{Effects of Atmospherics on Emotions}

During the provision of services and services, environmental stimuli affect consumer emotions which in turn affect their behavioral intentionsKoo and Ju (2010). Based on studies of retail stores, convention centers and restaurants and shopping centers, Breiter and Milman (2006), Kaltcheva and Weitz (2006), Koo and Ju (2010), Ong et al. (2012), and Tai and Fung (1997) confirm that the atmosphere has an impact on consumer experience and subsequent behavior. Kotler (1973) defines the atmosphere as a conscious space design to create certain buyer effects. The main objective is to increase the probability of purchasing. Key techniques include the application of colors, lighting, music, and decorations that are appropriate to the service environment (Koo and Ju, 2010; Ong et al., 2012; Tai and Fung, 1997). In the context of restaurants, Liu and Jang (2009) found that the atmosphere can influence consumer emotions;

\section{H3: There is an influence between Atmospherics and Emotions}

\section{Effect of Product Knowledge on Emotions}

Product knowledge in consumers includes general of the knowledge of facts, concepts and relationships relating to product services concerned Fryxell and Lo (2003). Statements such as: "When I compared my selfto my superiors and friends about this productl know morebetterthan them" is often used to assess consumer knowledge of a particular product. In the context of this study there is an influence on strengthening service quality, food quality, and restaurant atmosphere to emotions and consumer loyalty (Jang \&Namkung, 2009). Based on the level of the product knowledge the consumers will be build loyalty to a restaurant if they have hada positive emotional experiences during their visit (Norman \& Annie, 2015). Based on the literature then:

\section{H4: There is an influence between Product Knowledge and Emotions}

\section{Simultaneous influence between Food Quality, Service Quality, Atmospherics and Product Knowledge on Emotions}

Kwun and Oh (2006), Jang and Namkung (2009) and Wu and Liang (2009) found that the restaurant environment includes service quality, food quality, and atmosphere that can influence consumer emotions. In the context of research on luxury restaurants, service quality, food quality, and atmospherics can have an influence on consumer emotions which in the next stage can have an influence on brand loyalty (Norman and Annie, 2015).

H5: There is a simultaneous influence between Food Quality, Service Quality, Atmospherics andProduct Knowledge of Emotions

\section{Effect of Food Quality on Brand Loyalty}

To meet the basic needs and the main products of restaurants food has the ability; Therefore, regardless of whether the restaurant is a diner or fancy consumers will return and will be loyal if the food is of very good quality (Norman \& Annie, 2015) 
Factors Affecting Hedonic Brand Loyalty on the Fine Dining Indonesian Food Restaurant in Jakarta

H6: There is an influence between Food Quality on Brand Loyalty

\section{Influence between Service Quality on Brand Loyalty}

Findings from other studies that appeal to various research paradigms also provides support for the proposed relationship between employee behavior and emotional loyalty to a product or service which is a key factor influencing the relationship of consumer loyalty with brands (Erkmen and Hancer, 2015). In addition, employees who are friendly, polite and helpful are the main predictors of providing guests with a restaurant (Dortyol et al., 2014). Likewise communicative services, which refer to politeness, politeness, friendliness, attention, passion and employee attractiveness are closely related to the overall business partners (Durna et al., 2015). Following the logic of the argument above, the following hypothesis is made:

\section{H7: There is an influence between Service Quality on Brand Loyalty}

\section{Effect of Atmospheric on Brand Loyalty}

In the atmospheric marketing literature, it is defined as the design of space design to produce certain emotional effects on buyers that increase the probability of purchasing (Kotler, 1973). In restaurant studies atmospheric quality is understood as one crucial thing that builds on explaining service quality, which leads to positive influences and satisfaction of the intention to come back and be loyal to a product (Kincaid et al., 2010; Hoare and Butcher, 2008; and NamkungJang, 2008). Decoration is the most important thing related to authenticity in Chinese restaurants (George, 2001). The furniture is one of the most important design components that can influence consumer perceptions and evaluations. Music also represents a particular culture (George, 2001) and has a positive impact on service ( Hui et al., 1997).

\section{H8: There is an influence between Atmospherics on Brand Loyalty}

\section{Effect of Product Knowledge on Brand Loyalty}

Statements such as: "When 1 compared to mysuperiors\& friends, I so much know better about this product" is often used to assess consumer knowledge of a particular product. In the context of this study there is an influence on strengthening service quality, food quality, and restaurant atmosphere to emotions and consumer loyalty (Jang and Namkung, 2009).

\section{H9: There is an influence between Product Knowledge on Brand Loyalty}

\section{Effects of Emotions on Brand Loyalty}

Previous research on consumer behavior shows that positive emotions in consumers will make them loyal for example to revisit in the future (Flavian et al., 2001; Jeon and Hyun, 2012; Yoon and Uysal, 2005. Oliver (1999) suggested that Brand Loyalty is identified as a deep commitment or repeated purchases frequently on a product or service in the future. Brand loyalty shows the intensity of consumers to repeatedly visit the same restaurant. Research on consumers in a restaurant Jang \&Namkung (2009) and Jeon\& Hyun (2012) shows that there is a positive emotions or a self satisfaction with service products that can significantly influence brand loyalty, based on the literature, this study formulates the following hypotheses:

\section{H10: There is an influence of Emotions on Brand Loyalty}

\section{Simultaneous effects between Food Quality, Service Quality, Atmospherics, Product Knowledge and Emotions on Brand Loyalty}

Statements such as: "When compared to my friends and superiors, I know so much morebetter about this product" is often used to assess consumer knowledge of a particular product. In the context of this study there is an influence on strengthening service quality, food quality, and restaurant atmosphere to emotions and consumer loyalty (Jang \&Namkung, 2009). Based on the level of product knowledge consumers will build 
Factors Affecting Hedonic Brand Loyalty on the Fine Dining Indonesian Food Restaurant in Jakarta

loyalty to a restaurant if they have had positive emotional experiences during their visit (Norman \& Annie, 2015). Based on the literature then:

H11: There are simultaneous effects between Food Quality, Service Quality, Atmospherics, Product Knowledge and Emotions of Brand Loyalty Research Design

This study refers to the limitations of previous studies mainly conducted by Norman \& Annie (2015). Participants will be asked to fill 34 questions (questionnaires) and this study adopts the existing validity scale to assess the performance of Norman \& Annie (2015), Ruzica Brečić, Željka Mesic, Marija Cerjak, (2017), Reza Dabestani, ArashShahin, Mohammad Saljoughian, (2017), Michael R. Mullen ,Daire Hooper \& Joseph Coughlan (2013).

Populations of this study were all consumers who had come to the restaurant specified in the questionnaire more than one time.The sampling technique used in this study is to use Purposive Sampling. Purposive Sampling contains special people who can provide the desired information either,maybe that person is the only one who has information or that person meets the criteria determined by the researcher and is divided into two forms namely Judgment sampling and Quota sampling. In this study using the form of judgment sampling,which involves the selection of subjects placed in the most favorable place or in the best position to provide the information needed (Sekaran\& Bougie, 2009).

In determining sample size in a study it was stated that sample sizes that were too small or too large were not recommended, the number of respondents recommended in the sample range between 100-200 or 5 (five) to 10 (ten) samples for each parameter (indicator) in observation (Hair, Black \& Babin, 2013). In this study there were 34 indicators observed, so: $n=$ Number of parameters x $10 ; 34$ x $10=340$ respondents. With consideration of all the theoretical descriptions above, the number of samples used in this study amounted to 340 samples or respondents. Hypothesis testing is done by using multivariate analysis of structural equation models (Structural Equation Modeling or SEM and before questionnaires are distributed to all respondents to be tested, a preliminary study is conducted first by distributing questionnaires to 30 respondents. Data obtained from 30 respondents tested Validity and Reliability using SPSS 25 (Statistical Package for the Social Sciences).

Table1. Name, Address and Description of Restaurants as Research Samples

\begin{tabular}{|c|c|c|}
\hline No. & Restaurant Name & Address \\
\hline 1. & BungaRampai & Jl. Teuku Cik Ditiro No. 35, Menteng, Jakarta. Telp. (021) 31926224 \\
\hline 2. & KembangGoela & Plaza Sentral, Jl. Jenderal Sudirman, Sudirman, Jakarta. Telp. (021) 5205625 \\
\hline 3. & HarumManis & Apartemen Pavilion, Jl. KH Mas Mansyur, Sudirman, Jakarta. Telp. (021) \\
57941727
\end{tabular}

Source: Google 2017 data collection and analysis 


\section{DEVELOPMENT OF RESEARCH INSTRUMENTS}

The research instrument used in this study is a questionnaire which will be divided into 3 (three) groups, namely: questionnaire part A introduction which contains the introduction and benefits of filling out the questionnaire, questionnaire part B contains questions about the respondents' profile data consisting of six questions and at part $\mathrm{C}$ questionnaire which contains 34 statements relating to the variables to be studied. In part B of the questionnaire respondents were asked to choose according to their profile. In section $C$ questionnaire the existing statement is answered with a perception statement on the question with the Likert Scale answer with five scale points used when designing items with answer choices ranging from: SA (Strongly Agree), S (Agree), N (Neutral), NA (Not Agree) and SD (Strongly Disagree). In this study continued the limitations of the study by examining all the relationship variables to be studied in the ten luxury restaurants mentioned above where 34 questionnaires were distributed in each restaurant.

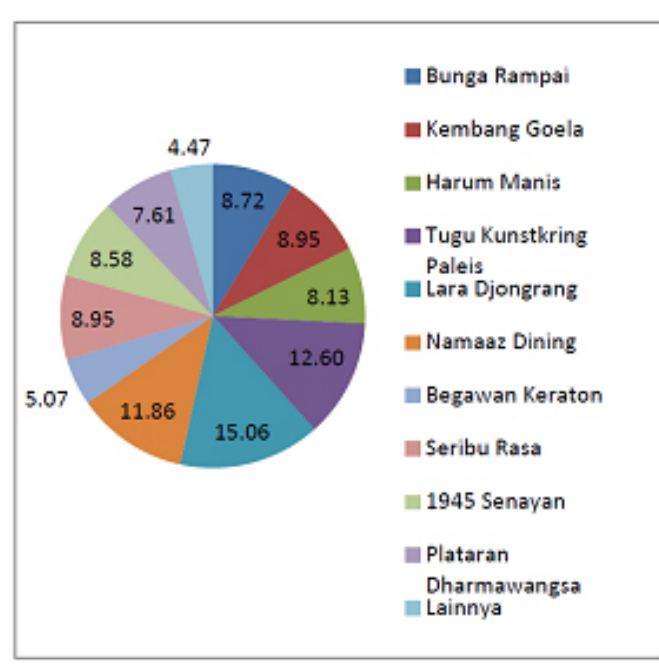

\begin{tabular}{c|}
\hline $\begin{array}{c}\text { Total } \\
\text { visit }\end{array}$ \\
\hline 117 \\
\hline 120 \\
\hline 109 \\
\hline 169 \\
\hline 202 \\
\hline 159 \\
\hline 68 \\
\hline 120 \\
\hline 115 \\
\hline 102 \\
\hline 60 \\
\hline Total :1341 \\
\hline
\end{tabular}

Fig2. Profile 1 Percentage of number of visits

Based on Profile 1 on the number of Visits and the largest and largest percentage in the period of \pm 6 months who visited Lara Djongrang restaurant 202 people (15.06\%) respondents from a total of 340 respondents and total visits $1341(100 \%)$.

Profile 2-6

Table2. Profile 2-6

\begin{tabular}{|c|c|c|c|}
\hline No. & Statements & Frequency & Percentage $(\%)$ \\
\hline \multirow{8}{*}{2.} & \multicolumn{3}{|l|}{ How many times have you visited within \pm 6 months? } \\
\hline & 2 times & 18 & 5.3 \\
\hline & 3 times & 36 & 10.6 \\
\hline & 4 times & 151 & 44.4 \\
\hline & 5 times & 83 & 24.4 \\
\hline & 6 times & 36 & 10.6 \\
\hline & $\geq 7$ times & 16 & 4.7 \\
\hline & Total & 340 & 100.0 \\
\hline \multirow{6}{*}{3.} & \multicolumn{3}{|l|}{ Average expenses for each visit } \\
\hline & $<$ Rp. 500.000 & 14 & 4.1 \\
\hline & Rp. 500.000 - Rp. 1.000 .000 & 86 & 25.3 \\
\hline & > Rp. 1.000 .000 - Rp. 1.500 .000 & 163 & 47.9 \\
\hline & $>$ Rp. 1.500 .000 & 77 & 22.7 \\
\hline & Total & 340 & 100.0 \\
\hline
\end{tabular}

American Research Journal of Business and Management

Page 8 
Factors Affecting Hedonic Brand Loyalty on the Fine Dining Indonesian Food Restaurant in Jakarta

\begin{tabular}{|c|c|c|c|}
\hline \multirow{4}{*}{4.} & Gender & & \\
\hline & Man & 199 & 58.5 \\
\hline & Women & 141 & 41.5 \\
\hline & Total & 340 & 100.0 \\
\hline \multirow{7}{*}{5.} & Ages & & \\
\hline & $<21$ years & 14 & 4.1 \\
\hline & $21-30$ years & 69 & 20.3 \\
\hline & $31-40$ years & 146 & 42.9 \\
\hline & $41-50$ years & 84 & 24.7 \\
\hline & $>50$ years & 27 & 7.9 \\
\hline & Total & 340 & 100.0 \\
\hline \multirow{6}{*}{6.} & Occupation & & \\
\hline & Government Employees & 11 & 3.2 \\
\hline & Private Company Employees & 116 & 34.1 \\
\hline & Entrepreneurship & 195 & 57.4 \\
\hline & \begin{tabular}{|l|} 
Others \\
\end{tabular} & 18 & 5.3 \\
\hline & Total & 340 & 100.0 \\
\hline
\end{tabular}

Profile 2 based on how many times they visited in a period of \pm 6 months can be described that of the total respondents 340 people (100\%) the largest frequency was 151 people (44.4\%) respondents who visited the restaurant 4 times.Based on Profile 3, the highest average expenditure for each visit was 163 people (47.9\%) who spent an average of $>$ Rp. 1,000,000 - Rp. 1,500,000. Profile 4 based on gender can be described that of the total respondents 340 people (100\%); there were 199 people (58.5\%) respondents were men. Profile 5 based on age can be described that of the total respondents 340 people (100\%), there are 14 people (4.1\%) respondents who are $<21$ years old; there are 69 people (20.3\%) respondents aged 21-30 years; there are 146 people (42.9\%) of respondents aged 31-40 years, there were 84 people $(24.7 \%)$ respondents aged $41-50$ years, there were 27 people (7.9\%) respondents aged $>50$ years .Profile 6 based on work can be described that the total respondents were 340 people (100\%), there were 11 people (3.2\%) respondents who worked as government employees; 116 people (34.1\%) respondents who work as employees of a private company; 195 people (57.4\%) respondents who became entrepreneurs and 18 people (5.3\%) respondents who had other jobs.

\section{VALIDITY AND RELIABILITY TESTING}

\section{Test of Validity}

Test 6 Variables measured by 34 indicators of test results show that the loading value is greater than 0.30 (Hair, $\mathrm{n}=340$ ) so it can be concluded that the 34 indicators are able to form variables Food Quality, Service Quality, Atmospheric, Product Knowledge, Emotion and Brand Loyalty or valid.

\section{Reliability}

Reliability test uses cronbach's alpha analysis tool, where each observed variable is declared reliable (consistent) if it has an alpha cronbach's value $>0.6$ (Uma Sekaran, 2000). There are also results from reliability testing for each variable in this study that can be reliably seen in the following table:

Table3. Test Results Reliability

\begin{tabular}{|c|c|c|}
\hline Variable & Cronbach Alpha & Conclusion \\
\hline Food Quality & 0.856 & Reliable \\
\hline Service Quality & 0.856 & Reliable \\
\hline Atmospherics & 0.856 & Reliable \\
\hline Product Knowledge & 0.856 & Reliable \\
\hline Emotion & 0.856 & Reliable \\
\hline Brand Loyalty & 0.856 & Reliable \\
\hline
\end{tabular}


Factors Affecting Hedonic Brand Loyalty on the Fine Dining Indonesian Food Restaurant in Jakarta

Table4. Model Suitability Index Results

\begin{tabular}{|c|c|c|c|}
\hline Indicator & Cut-Off & Results of Estimated & Conclusions \\
\hline Chi-Square & Approaches 0 & 2593.88 & Not Goodness \\
\hline RMSEA & $\leq 0.08$ & 0.12 & Not Goodness \\
\hline GFI & $\geq 0.90$ & 0.64 & Not Goodness \\
\hline AGFI & $\geq 0.90$ & 0.59 & Not Goodness \\
\hline NFI & $\geq 0.90$ & 0.87 & Not Goodness \\
\hline CFI & $\geq 0.90$ & 0.90 & Goodness of Fit \\
\hline PNFI & The higher the better & 0.80 & Goodness of Fit \\
\hline PGFI & <from GFI and getting smaller the better & 0.78 & Not Goodness \\
\hline
\end{tabular}

According to Hair et al (2013) the formed model can be accepted at the level of fit and marginal if there are one or two criteria for the Goodness of Fit Index that have been met. Test results show that the criteria used to measure model suitability are absolute fit measures, incremental fit measures, and parsimonius fit measures. The structural model proposed in this study passed on two criteria, namely the criteria for incremental fit measures (CFI) and parsimonious fit measures (PNFI). Thus, overall, the proposed structural model has good ability in terms of matching data (good fit) so that the analysis can be continued in the subsequent analysis.

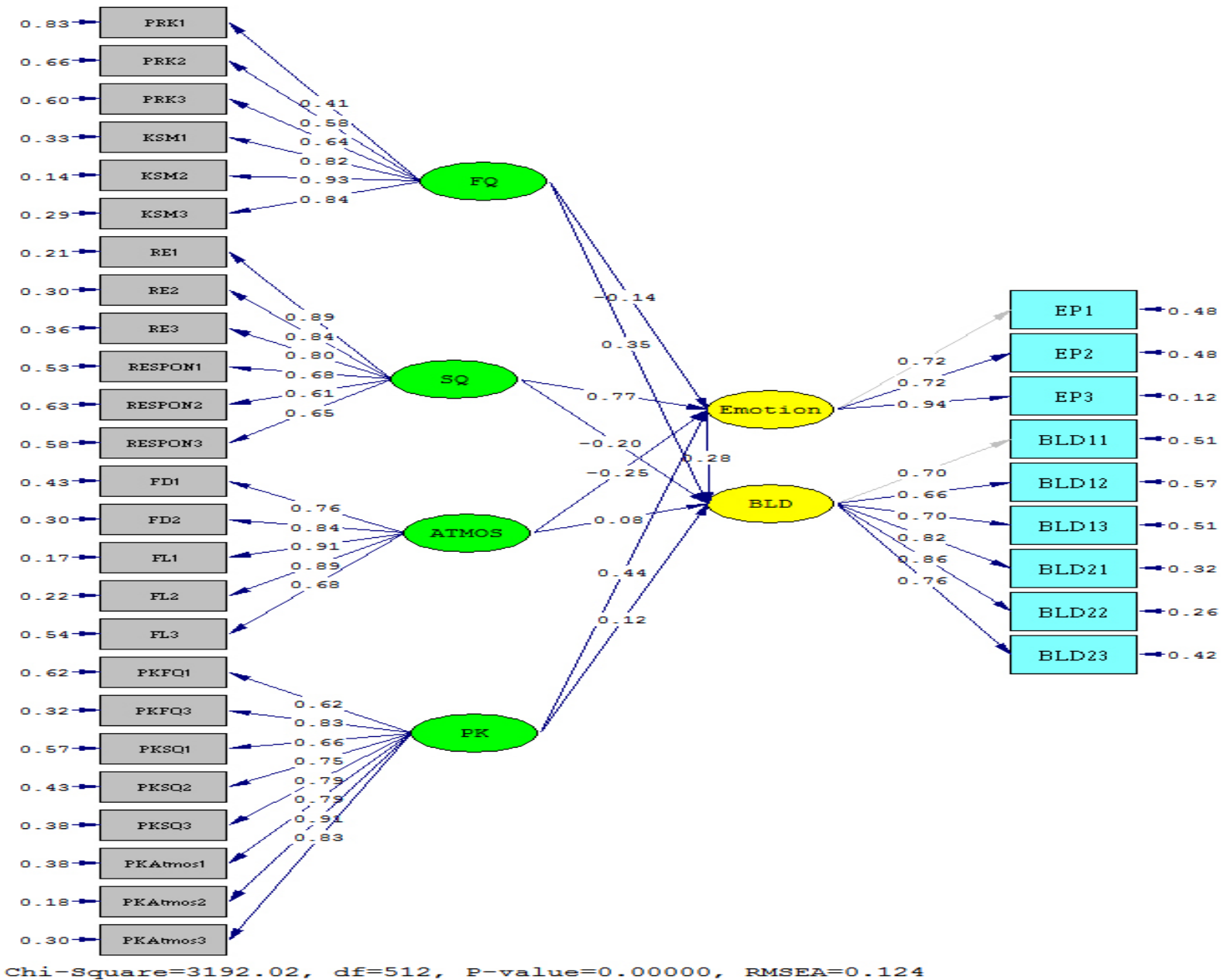

Fig3. Overall Structural Equation Model (Estimates) 


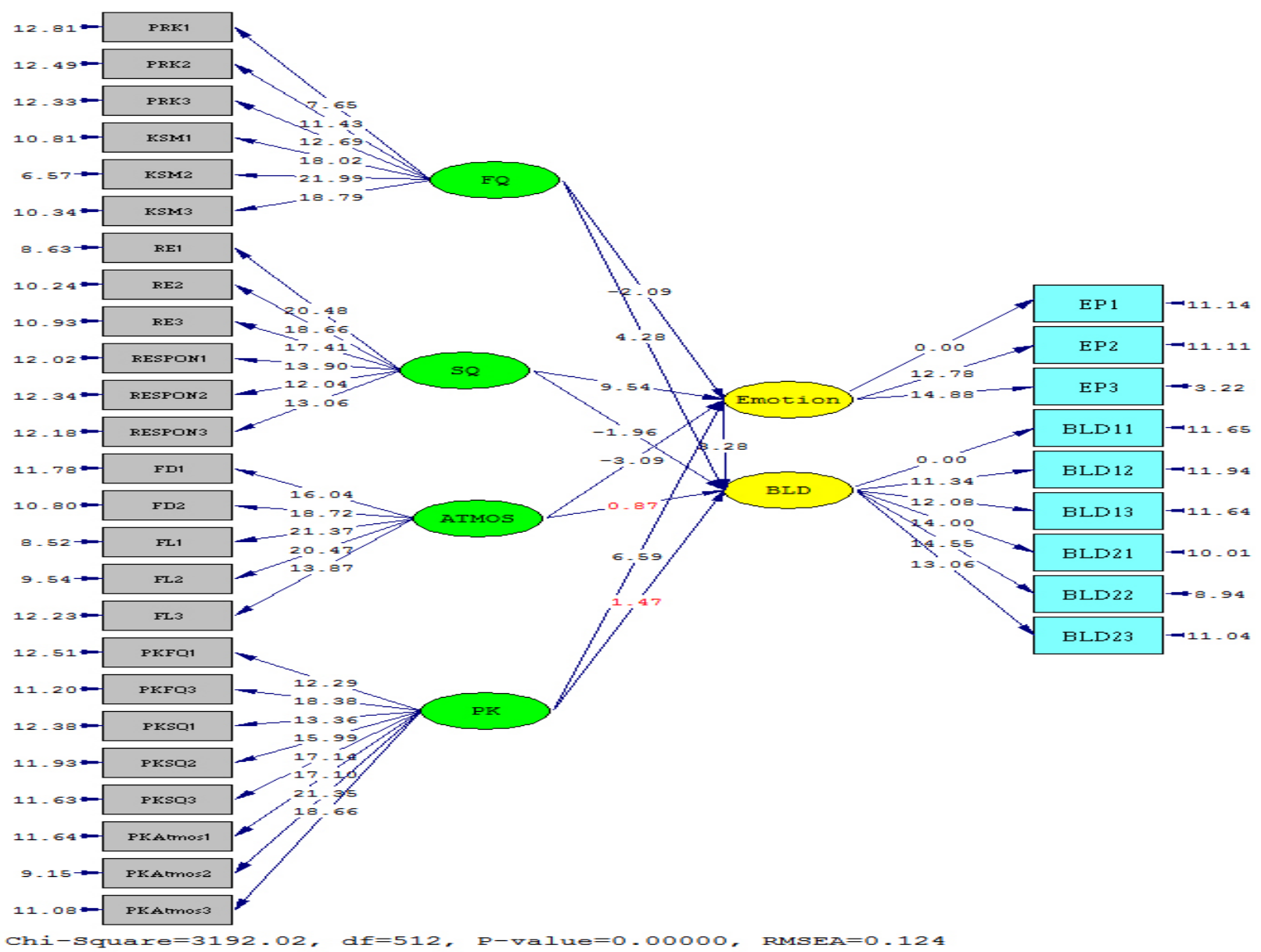

Fig4. Overall Structural Equation Model (T-Value)

\section{HYPOTHESIS TESTING}

The results obtained for the Structural Equations model in accordance with the hypothesis proposed are:

\section{Equation 1:}

Emotion $=-0.14 * \mathrm{FQ}+0.77 * \mathrm{SQ}-0.25 * \mathrm{ATMOS}+0.44 * \mathrm{PK}$,

Errorvar. $=0.52, \mathrm{R}^{2}=0.48$

$$
\begin{aligned}
& (0.068)(0.081)(0.082)(0.081)(0.067)(0.076) \\
& -2.099 .54-3.099 .546 .596 .77
\end{aligned}
$$

\section{Equation 2:}

$\mathrm{BLD}=0.34 * \mathrm{FQ}-0.20 * \mathrm{SQ}+0.081 * \mathrm{ATMOS}+0.12 * \mathrm{PK}+0.28 *$ Emotion,

Errorvar. $=0.74, \mathrm{R}^{2}=0.26$

$$
\text { (0.080) (0.10) (0.094) (0.079) (0.085) (0.11) }
$$

$$
4.28-1.960 .871 .473 .286 .98
$$

Where : 
Factors Affecting Hedonic Brand Loyalty on the Fine Dining Indonesian Food Restaurant in Jakarta

Emotion: Emotion ;FQ: Food Quality;SQ: Service Quality;ATMOS: Atmospherics;PK: Product Knowledge;BLD: Brand Loyalty

(Source: Output Lisrel 8.80)

Based on structural equations 1. it can be seen the magnitude of the loading coefficient of Food Quality to Emotions variable is -0.14 , the magnitude of the loading coefficient Service Quality to Emotions variable is 0.77, the magnitude of the Atmospheric variable loading coefficient for Emotions is - 0.25, the magnitude of the loading factor of the Product Knowledge variable on Emotions is 0.44.

Based on structural equations 2. it can be seen the magnitude of the loading coefficient of the Food Quality variable on Brand Loyalty is 0.34 , the magnitude of the Service Quality variable loading coefficient on Brand Loyalty is- 0.20, the magnitude of Atmospherics variable loading coefficient for Brand Loyalty is 0.081, the amount of the path factor (loading factor) Product Knowledge variable to Brand Loyalty is 0.12 and the magnitude of the loading coefficient (Emotions) variable for Brand Loyalty is 0.28 .

\section{Discussion OF ANALYSis RESUlts}

\section{H1: There is an Influence between Food Quality and Emotions}

Based on the test results obtained t-value is equal to $-2.09>\mathrm{t}$-table 1.97 , then $\mathrm{H} 0$ is rejected and $\mathrm{H} 1$ is accepted or supported and there is a negative and significant influence between the two variables with indicator values (KSM2) in the dimensions of Health Characteristics and Sensory Food as a reflector the highest is 0.93.The results of this study are in line with the research by Jang and Namkung (2009) where luxury restaurant stimuli have three factors (namely food quality, service quality, and atmosphere) that can significantly influence visitor emotions. One of the results of this study shows that the quality of food is superior (i.e. food and drink does not affect emotions. In his research found the relationship between food quality and positive emotions became insignificant. They argue that having fresh and healthy food is a standard requirement for a restaurant and thus visitors will not be happy just because the quality of the food is good. One possible explanation for this difference is related to the research context. Jang and Namkung may be valid when applied to service restaurants complete ,but not a fancy restaurant

\section{H2: There is an Influence between Service Quality on Emotions}

Based on the test results obtained $\mathrm{t}$-value is equal to $9.54>\mathrm{t}$-table 1.97, then $\mathrm{H} 0$ is rejected and $\mathrm{H} 2$ is accepted or supported and there is a positive and significant influence between the two variables with the indicator value (RE1) in dimensions Reliability as the highest reflector is 0.89 . this research is consistent and also supports the opinions of Jang and Namkung, 2009; Kwun and Oh, 2006; Wu and Liang (2009) In the context of serving food to consumers restaurant employees interact directly with consumers during their visits and it has been confirmed that staff service quality influences consumer emotions (Jang and Namkung, 2009; Kwun and Oh, 2006).

\section{H3: There is an Influence between Atmospherics and Emotions}

Based on the test results, it was found that the value of t-value was -3.09>t-table 1.97, then $\mathrm{H} 0$ was rejected and H3 was accepted or supported and there was a negative and significant influence between the two variables with indicator value (FL1) in the Environmental Factor dimension as the highest reflector of 0.91 . The results of this study are supported by previous research conducted by Koo and Ju (2010) who suggested that during the provision of services and services, environmental stimuli affect consumer emotions which in turn affect their behavioral intentions. Based on studies of retail stores, convention centers, restaurants and shopping centers Breiter and Milman (2006), Kaltcheva and Weitz (2006), Koo and Ju (2010), Ong et al. (2012), and Tai and Fung (1997) also confirmed that the atmosphere had a profound impact on consumer experience and subsequent 
behavior which included the application of color, lighting, music, and decorating that was appropriate to the service environment (Koo and Ju, 2010; Ong et al., 2012; Tai and Fung, 1997) . In the context of the restaurant Liu and Jang (2009) also found that the atmosphere can influence consumer emotions.

\section{H4: There is an Influence between Product Knowledge and Emotions}

Based on the test results, the t-value is equal to 6.59> t-table 1.97, then $\mathrm{H} 0$ is rejected and $\mathrm{H} 4$ is accepted or supported and there is a positive and significant influence between the two variables with the indicator value (PKAtmos2) comparing with others, friends and Other visitors will understand Atmospherics as the highest reflector of 0.91 . The results of testing the fourth hypothesis are in line with the results of research conducted by Jang and Namkung (2009), namely " "When i compared with my superiors and my friends, about this product i know much better than them"' often used to assess consumer knowledge of a particular product. In the context of this study there is an influence on strengthening service quality, food quality, and restaurant atmosphere to emotions.

\section{H5: There is a Simultaneous Influence between Food Quality, Service Quality, Atmospherics and Product Knowledge on Emotions}

Based on the test results obtained F-count value of 61.66> F-table 2.40, then $\mathrm{H} 0$ is rejected and $\mathrm{H} 6$ is supported or accepted and there is a positive and significant simultaneous influence between the five variables with service quality variable as the highest reflector of 0.77 . The results of this study also support research conducted by Jang and Namkung (2009), Kwun and Oh (2006) and Wu and Liang (2009) where the restaurant environment includes service quality, food quality, visitor knowledge and atmosphere that can affect consumer emotions. In the context of restaurant research luxury service quality, food quality, product knowledge and atmospherics can have a positive influence on consumer emotions, which in the next stage can have an influence on brand loyalty (Norman and Annie, 2015).

\section{H6: There is an Influence between Food Quality on Brand Loyalty}

Based on the results of the test, the value of t-value is 4.28>t-table 1.97, then $\mathrm{H} 0$ is rejected and $\mathrm{H} 7$ is supported or accepted there is also a positive and significant influence betweenboth variables with indicator indicator values (KSM2) in the dimensions of health and sensory food dimensions as the highest reflector of 093. The results of this study are in line with the results of the study conducted by Norman \& Annie (2015) that food has the ability to meet basic needs and main products of restaurants therefore, regardless of whether the restaurant is an ordinary restaurant or a luxury the consumer will return and be loyal if the food is of very good quality.

\section{H7: There is an Influence between Service Quality on Brand Loyalty}

Based on the test results obtained t-value of $-1.96<\mathrm{t}$-table 1.97, then H0 is accepted and H8 is rejected also there is a negative and not significant influence between the two variables. In line with the results of research conducted by Putri et al (2016) which examined The Influence of Service Quality on Brand Loyalty concluded that poor service will have a negative and not significant impact on IndiHome Brand Loyalty Bandung.

\section{H8: There is an Influence between Atmospherics on Brand Loyalty}

Based on the test results, the t-value is $0.87<\mathrm{t}$-table 1.97 , then $\mathrm{H} 0$ is accepted and $\mathrm{H} 9$ is rejected, there is also a positive and not significant effect between the two variables with the indicator value (FL1) in the Environmental Factor dimension as the highest reflector of 0.91. this study also supports the research conducted by Rahmatika and Yuliviona (2014) which states that there are positive and insignificant influences between atmosphere and brand loyalty, the better store atmosphere, the higher brand loyalty will be at Enhai Cafe assuming other variables besides store atmosphere considered constant, and vice versa the more it is not good store atmosphere, the lower the loyalty.

American Research Journal of Business and Management

Page 13 
Factors Affecting Hedonic Brand Loyalty on the Fine Dining Indonesian Food Restaurant in Jakarta

H9: There is an Influence between Product Knowledge on Brand Loyalty

Based on the test results obtained t-value is equal to $1.47<\mathrm{t}$-table 1.97, then $\mathrm{H} 0$ is accepted and $\mathrm{H} 9$ is rejected and there is a positive and insignificant influence between the two variables with the indicator indicator value (PKAtmos2) in comparing with others, friends and Other visitors will understand Atmospherics as the highest reflector of 0.91 . The result of testing the fifth hypothesis is in line with the research conducted by Norman \& Annie (2015) that based on the level of product knowledge consumers will build loyalty to a restaurant if they have emotional experiences positive during their visit.

\section{H10: There is an Influence of Emotions on Brand Loyalty}

Based on the test results obtained t-value of 3.28>t-table 1.97, then H0 is rejected and H10 is supported or accepted there is also a positive and significant influence between the two variables with the indicator value (EP3) in the Positive Emotional dimension as the highest reflector of 0.94. In line with the results of previous research on consumer behavior shows that positive emotions in consumers will make them loyal for example to revisit in the future (Flavian et al., 2001; Jeon and Hyun, 2012; Yoon and Uysal, 2005. Oliver (1999) suggests that Brand Loyaltyidentified as a deep commitment or repeated purchases frequently for a product or service in the future Brand loyalty shows the intensity of consumers to repeatedly visit the same restaurant. Consumer Emotion Research has significant implications because of the way consumers perceive, when consuming services or products influences decision making, repetition of arrivals, satisfaction, loyalty, complaints and switching behavior (Stephens and Gwinner, 1998; Dewitt and Brady, 2003; Han et al., 2009). The results of research on consumers in a restaurant Jang and Namkung (2009) and Jeon and Hyun (2012) show that there are positive emotions or a certain satisfaction with service products that can significantly influence brand loyalty.

\section{H11: Simultaneous Effects between Food Quality, Service Quality, Atmospherics and Product Knowledge, and Emotions on Brand Loyalty}

Based on the test results, obtained F-stat value of 15.65> F-table 2.24, then $\mathrm{H} 0$ is rejected and $\mathrm{H} 11$ is supported or accepted and there is a positive and significant simultaneous influence between the six variables with service quality variable as the highest reflector of 0.77.Stimuli (stimulation ) in restaurants can influence consumer positive and negative emotions that will affect their loyalty to fancy restaurants also offer new empirical support for consumer expectation propositions that play a role in building consumer loyalty and provide theoretical nuances as well as managerial understanding of the process of consuming fancy restaurants (Annie \& Norman , 2014) also based on the level of product knowledge consumers will build loyalty to a restaurant if they have had positive emotional experiences during their visit (Norman \& Annie, 2015).

\section{Conclusion of Implications AND Suggestions For Future ReSEARCH}

\section{Conclusion}

Food Quality at luxury Indonesian food restaurants proved to have a negative and significant effect on Emotion. The results showed that supporting data from the first hypothesis produced a path coefficient of -0.14 and a t-statistic of -2.09 implies that there are negative and significant relationships between the two variables with indicator values (KSM2) in the dimensions of Health Characteristics and Food Sensory as the highest reflector of 0.93 . Service Quality at luxury Indonesian food restaurants has a positive and significant effect on Emotion. The results showed that the supporting data from the second hypothesis produced a path coefficient of 0.77 and a t-statistic of 9.54 implies that there is a positive and significant relationship between the two variables with the indicator value (RE1) in the dimensions of reliability as the highest reflector of 0.89 . Indonesia has a negative and significant effect on Emotion. The results showed that supporting data from the third hypothesis produced a path coefficient of -0.25 and a t-statistic of -3.09 implies that there is a negative and significant relationship between the two variables with the indicator value (FL1) in the Environmental Factor dimension as the highest reflector of 0.91 .

American Research Journal of Business and Management

Page 14 
Product Knowledge in luxury Indonesian food restaurants has a positive and significant effect on Emotion. The results showed that supporting data from the fourth hypothesis produced path coefficients 0.44 and t-statistics of 6.59 implying that there is a positive and significant relationship between the two variables with the indicator value (PKAtmos2) in comparing with other people, friends and other visitors will understand Atmospherics as highest reflector of 0.91. Food Quality, Service Quality, Atmospherics and Product Knowledge in luxury restaurants of typical Indonesian food have a positive effect and simultaneously contribute to a positive and significant effect on Emotions. The results of the study show that supporting data from the sixth hypothesis produces a F-count (61.66) > of F -table (2.40) implies that there is a positive and significant simultaneous contribution between the five variables with the variable service quality as the highest reflector of 0.77 . Food Quality in luxury restaurants of typical Indonesian food has a positive and significant effect on Brand Loyalty. The results showed that supporting data from the seventh hypothesis produced path coefficients 0.34 and t-statistics of 4.28 implying that there was a positive and significant relationship between the two variables with indicator values (KSM2) in the dimensions of health and sensory food as the highest reflector of 0.93.

Service Quality in luxury restaurants of typical Indonesian food has a negative and not significant effect on Brand Loyalty. The results showed that supporting data from the eighth hypothesis produced a path coefficient of -0.20 and a t-statistic of -1.96 implies that there is a negative and insignificant relationship between the two variables. Atmospherics in Indonesian fine-dining restaurants have a positive and not significant effect on Brand Loyalty. The results showed that supporting data from the ninth hypothesis produced path coefficients 0.08 and t-statistics of 0.87 implying that there is a positive and not significant relationship between the two variables with the indicator value (FL1) in the Environmental Factor dimension as the highest reflector of 0.91. Product Knowledge in restaurants luxury Indonesian food has a positive and not significant effect on Brand Loyalty. The results showed that the supporting data from the fifth hypothesis produced path coefficients 0.12 and t-statistics of 1.47 implying that there was a positive and insignificant relationship between the two variables with the indicator indicator value (PKAtmos2) comparing with other people, friends and other visitors of understanding. Atmospherics as the highest reflector of 0.91 .

Emotion in fancy Indonesian food restaurants has a positive and significant effect on Brand Loyalty. The results showed that supporting data from the tenth hypothesis produced path coefficients 0.28 and $t$-statistics of 3.28 implying that there was a positive and significant relationship between the two variables with indicator values (EP3) in the Positive Emotional dimension as the highest reflector of 0.94. Food Quality, Service Quality, Atmospherics, Product Knowledge and Emotions simultaneously contribute to a positive and significant influence on Brand Loyalty. The results showed that the supporting data from the eleventh hypothesis resulted in the value of F-count (15.65) > from F-table (2.24) implying there was a positive and significant simultaneous contribution between the six variables with the service quality variable as the highest reflector of 0.77.

\section{THEORETICAL IMPLiCATIONS AND MANAGERIAL IMPLiCATIONS}

\section{Theoretical Implications}

Based on the results of this study, there are several important things that can contribute useful theories for the development of science, including adding contrasting empirical findings on the relationship between Food Quality, Atmospherics to Emotions and Service Quality on Brand Loyalty which turns out to have a negative and insignificant effect. This finding is intuitively different from the research previously conducted by Norman Peng et al (2015). These findings should then be further examined and tested in different research settings, but this finding enriches the service marketing literature and through this research some empirical support is provided based on previous research, namely the relationship between Service Quality to Emotions, Food Quality to Brand Loyalty, Atmospherics to Brand Loyalty and Emotion for Brand Loyalty, where the positive findings generated from this study support the findings conducted by Norman Peng et al (2015). 
In this study also get new empirical findings on Product Knowledge on Emotion and Product Knowledge on Brand Loyalty, where the positive findings generated from this study are different from findings made by Norman Peng et al (2015) where Product Knowledge is used as a moderating variable in Previous research is therefore a finding that enriches the literature insight on Product Knowledge. In this study also obtained new empirical findings on the relationship of Food Quality, Service Quality, Atmospherics and Product Knowledge to Emotions implying that there is a positive relationship, simultaneously contributing and significant between the five variables then the relationship of Food Quality, Service Quality, Atmospherics, Product Knowledge and the emotion of Brand Loyalty implies that there is a positive relationship, simultaneously contributing and significant between the six variables which is different from the findings made by Norman Peng et al (2015) which do not carry out simultaneous testing among the variables therefore this finding enriching the literature's insights on Emotions and Brand Loyalty.

\section{Managerial Implications}

For Indonesian luxury dining restaurants, the results of this study have some managerial implications. The findings of this study can help luxury restaurant owners and managers as well as their marketing department to better understand how each type of stimulus can influence consumer emotions that in turn affects loyalty. Food Quality at Indonesian luxury food restaurants has a negative and significant effect on Emotion so it must be improved and pay attention to the Health Characteristics and Sensory Food in order to better build good emotions towards their customers.

In the context of a fancy restaurant, the variables of food quality, service quality, quality and atmosphere (Atmospherics) and product knowledge simultaneously contribute to a positive and significant influence on emotions with service quality variables being very instrumental variables so that it is expected that pay more attention and increase the reliability of its employees by providing a comprehensive quality of service to be able to build good and positive emotions and satisfy their customers. Food Quality, Service Quality, Atmospherics, Product Knowledge and Emotions simultaneously contribute to a positive and significant impact on Brand Loyalty there is a positive and significant simultaneous relationship between the six variables with service quality variables as the dominant variable so it must be improved and considered the reliability of its employees by creating employees who can be relied upon to provide quality comprehensive services to be able to build loyalty or loyalty to the restaurant.

\section{SUGGESTIONS FOR FURTHER RESEARCH}

Based on the demographic and restaurant background of the characteristic participants, the emphasis of this study is that 10 luxury Indonesian food restaurants in Jakarta have exclusive luxury restaurants outside of Jakarta or even throughout Indonesia which would be interesting to explore whether this study model can explain consumer consumption behavior in fancy restaurants of typical Indonesian food that have famous brand names or just ordinary restaurants or with other luxury Franchise restaurants. Variable Service Quality only measures based on Empathy and Responsiveness will be better if further research measures using five indicators of Parasuraman namely: Tangibels, Empathy, Reliability, Responsiveness, Assurance (1988). Variables of negative emotions can be tried to be used for further investigation so they can know their influence when studying the consumption of luxury restaurants.

\section{REFERENCES}

Annie Chen, Norman Peng, Kuang-peng Hung, (2014) “The effects of luxury restaurant environments on diners' emotions and loyalty: Incorporating diner expectations into an extended Mehrabian-Russell model", International Journal of Contemporary Hospitality Management, Vol. 27 Issue: 2, pp.236-260.

American Research Journal of Business and Management

Page 16 
Factors Affecting Hedonic Brand Loyalty on the Fine Dining Indonesian Food Restaurant in Jakarta

Baker, J., Grewal, D. and Parasuraman, A. (1994), "The influence of the store environment on quality inferences and store image", Journal of the Academy of Marketing Science, Vol. 22,pp. 328-39.

Berman dan Evans, 2010. "Retail Management". 12th Edition. Jakarta; Pearson

Bilgihan, A. (2016). Gen Y customer loyalty in online shopping: An integrated model of trust, user experience and branding. Computers in Human Behavior, 61, 103-113.

Ben Khelil, H. and Bouslama, N. (2013), "L'impact de la perception de la qualité du service sur le prosélytisme: cas des fournisseurs de service Internet en Tunisie", 4èmejournées de l'Unité de Recherche et Applications en Marketing (URAM), Hammamet, Tunis.

Breiter, D., \& Milman, A. (2006). Attendees' needs and service priorities in a large convention center: Application of the importance-performance theory. Tourism Management, 27(6), 1364-1370.

Bowen,Jhon .T \& Shiang-Lih Chen Mc.Cain(2015)"Transitioning loyalty program: A commentary on the relationship between customer loyalty and customer satisfaction"International Journal of contemporary hospitality management, Vol.27 Issue:3,pp.415-430.

Brucks, Merrie (1984), "The Effects of Product Class Knowledge on Information Search Behavior," unpublished dissertation, Graduate School of Industrial Administration, Carnegie-Mellon University, Pittsburgh, PA 15213.

Bruck, Merry (1984)"The effect of product class knowledge on information search behavior"unpublish dissertation,Graduate school of industrial administration,Carnegic mellon university,Pittsburgh,PA 15213.

Brunner-Sperdin, A., Peters, M. and Strobl, A. (2012), "It is all about the emotional state: managing tourists' experiences", International Journal of Hospitality Management, Vol. 31 No. 1, pp. 23-30.

Chaudhuri,A; Morris B Holbrook,"The Chain of Effect from Brand Trust and Brand Effect to brand preformance: The Role of Brand Loyalty". Journal of Market Focused Management, 2001

Chen, Kuang; Jung and Chu Mei Liu, 2004, Positive Brand Extension Trial and Choice of Parent Brand, Journal of Product \& Brand Management, Vol. 13: 25 - 36.

Cristau, C. (2003), “Définition, mesure et modélisation de l'attachement a` une marque comme la conjonction de deux dimensions distinctes et concomitantes: la dépendance et l'amitié vis-a`-vis de la marque”, Congrès International, Les Tendances du Marketing, Venise, pp. 28-29.

Chow, I. H.-s., Lau, V. P., Lo, T. W.-c., Sha, Z., \& Yun, H. (2007). Service quality in restaurant operations in China: Decision- and experiential-oriented perspectives. International Journal of Hospitality Management, 26(3), 698-710.

Daire Hooper,Joseph Coughlan, Michael R. Mullen, (2013) "The servicescape as an antecedent to service quality and behavioral intentions", Journal of Services Marketing, Vol. 27 Issue: 4, pp.271-280, https://doi. org/10.1108/08876041311330753

Devlin, J.F., Gwynne, A.L. and Ennew, C.T. (2002), “The antecedents of service expectations", Service Industries Journal, Vol. 22 No. 4, pp. 117-136.

Dortyol, I., Varinli, I. and Kitapci, O. (2014), “How do international tourists perceive hotel quality?", International Journal of Contemporary Hospitality Management, Vol. 26 No. 3,pp. 470-495.

American Research Journal of Business and Management

Page 17 
Durna, K., Dedeoglu, B. and Balikçioglu, S. (2015), "The role of servicescape and image perceptions of customers on behavioral intentions in the hotel industry", International Journal of Contemporary Hospitality Management, Vol. 27 No. 7, pp. 1728-1748.

Erkmen, E. and Hancer, M. (2015), “Do your internal branding efforts measure up?", International Journal of Contemporary Hospitality Management, Vol. 27 No. 5, pp. 878-895.

Evan, N. (2016), "Sustainable competitive advantage in tourism organizations: a strategic model applying service dominant logic and tourism's defining characteristics", TourismManagement Perspectives, Vol. 18, pp. 14-25.F

Fallahi, M. \& Nameghi, M. G. (2013). A study of the effects of brand personality on three constructs: Brand trust, brand attachment, and brand commitment in Imam Khomeini port city. Interdisciplinary Journal of Contemporary Research in Business, 5(8), 156-169.

Flavian, C., Martinez, E. and Polo, Y. (2001), "Loyalty to grocery stores in the Spanish market of the 1990s", Journal of Retailing and Consumer Services, Vol. 8 No. 2, pp. 85-93.

Fryxell, G. and Lo, C. (2003), "The influence of environmental knowledge and values on managerial behaviors on behalf of the environmental: an empirical examination of managers in China", Journal of Business Ethics, Vol. 46, pp. 45-49.

George, R.T. (2001). Dining Chinese: a consumer subgroup comparison. Journal of Restaurant \& Foodservice Marketing, 4(2), 67-86

Gurviez, P. (1999), "La confiancecomme variable explicative du comportement du consommateur: proposition et validation d'un modèle de la relation a' la marque intégrant la confiance", Actes du Congrès International de l'Associationfrançaise du Marketing, Strasbourg, pp. 301-327.

Grunert, K.G., Larsen, H.H., Madsen, T.K. and Baadsgaard, A. (1996), Market Orientation in Food and Agriculture, Kluwer, Boston, MA.

Grunert, K.G. (2005), "Food quality and safety: consumer perception and demand", European Review of Agricultural Economics, Vol. 32 No. 3, pp. 369-391.

Guillard,V.and Roux, D. (2014), "Macromarketing issues on thesidewalk: how'gleaners' and 'disposers' (Re) create a sustainable economy”, Journal of Macromarketing, Vol. 34 No. 3.doi: 10.1177/0276146713518562.

Hair, J.F., Black, W.C., Babin, B.J., \& Anderson, R.E., 1998, Multivariate Data Analysis Fifth Edition, Prentice Hall: New Jersey.

Ha, J. and Jang, S.S. (2010), "Effects of service quality and food quality: the moderating role of atmospherics in an ethnic restaurant segment”, International Journal of Hospitality Management, Vol. 29 No. 3, pp. 520-529.

Ha, J. and Jang, S.S. (2013), “Attributes, consequences, and consumer values: a means-end chain approach across restaurant segments", International Journal of Contemporary Hospitality Management, Vol. 25 No. 3, pp. 383-409.

Han, H. and Ryu, K. (2009), "The roles of the physical environment, price perception, andcustomer satisfaction in determining customer loyalty in the restaurant industry", Journalof Hospitality and Tourism Research, Vol. 33 No. 4, pp. 487-510.

Han, Y.J., Nunes, J.C. and Dreze, X. (2010a), "Signaling status with luxury goods: the role of brand prominence”, Journal of Marketing, Vol. 74 No. 4, pp. 15-30.

American Research Journal of Business and Management

Page 18 
Han, H., and Jeong, C. (2013). "Multi-dimensions of Patrons' Emotional Experiences in Upscale Restaurants and their Role in Loyalty Formation: Emotion Scale Improvement". International Journal of Hospitality Management, 32, March, 59-70.

Hung, K.-P., Chen, A.H., Peng, N., Hackley, C., Tiwsaku, A.R. and Chou, C.-L. (2011), "Antecedents of luxury brand purchase intention", Journal of Product \& Brand Management, Vol. 20 No. 6, pp. 456-467.

Han, H. and Ryu, K. (2009), "The roles of the physical environment, price perception, and customer satisfaction in determining customer loyalty in the restaurant industry", Journal of Hospitality \& Tourism Research, Vol. 33 No. 4, pp. 487-510.

Harris, Lloyd.C \&Chris Ezeh, (2008) “Servicescapeandloyaltyintentions: an empiricalinvestigation”, European Journal of Marketing, Vol. 42 Issue: 3/4, pp.390-422, https://doi.org/10.1108/03090560810852995

Hui M, Dube L, Chebat J-C. The impact of music on consumers' reaction to waiting for services. J Retail 1997;73(1):87 - 104

Hwang, J. and Kandampully, J. (2012), "The role of emotional aspects in younger consumer-brand relationships", Journal of Product and Brand Management, Vol. 21 No. 2, pp. 98-108.

Hare,Rui Jin \& Ken Butcher, (2008) “Do Chinese cultural values affect customer satisfaction/ loyalty?", International Journal of Contemporary Hospitality Management, Vol. 20 Issue: 2, pp.156171, https://doi.org/10.1108/09596110810852140.

Jang, S.(S.) and Namkung, Y. (2009), "Perceived quality, emotions, and behavioural intentions: application of an extended Mehrabian-Russell model to restaurants", Journal of Business Research, Vol. 62 No. 4, pp. 451460.

Jani, D. and Han, H. (2015), "Influence of environmental stimuli on hotel customer emotional loyalty response: testing the moderating effect of the big five personality factors", International Journal of Hospitality Management, Vol. 44, pp. 48-57.

Jeon, S.M. and Hyun, S.S. (2012), "Examining the influence of casino attributes on baby boomers'satisfaction and loyalty in the casino industry", Current Issues in Tourism, Vol. 16 No. 4,pp. 343-368.

Kandampully, J., Zhang, T. and Bilgihan, A. (2015), "Customer loyalty: a review and future directions with a special focus on the hospitality industry", International Journal of Contemporary Hospitality Management, Vol. 27 No. 3, pp. 379-414.

Kaltcheva, V.D. and Weitz, B.A. (2006), "When should a retailer create an exciting store environment", Journal of Marketing, Vol. 70 No. 1, pp. 107-118.

King, S.C. and Meiselman, H.L. (2010), "Development of a method to measure consumer emotions associated with foods", Food Quality and Preference, Vol. 21 No. 2, pp. 168-177.

King, S.C., Meiselman, H.L. and Carr, B.T. (2010), "Measuring emotions associated with foods in consumer testing", Food Quality and Preference, Vol. 21 No. 8, pp. 1114-1116.

Kincaid, C., Baloglu, S., Mao, Z. and Busser, J. (2010), "What really brings them back? The impact of tangible quality on affect and intention for casual dining restaurant patrons",International Journal of Contemporary Hospitality Management, Vol. 22 No. 2,pp. 209-220.

Koo, D.M. and Ju, S.H. (2010), "The interactional effects of atmospherics and perceptual curiosity on emotions and online shopping intention", Computers in Human Behavior, Vol. 26 No. 3,pp. 377-388.

American Research Journal of Business and Management

Page 19 
Factors Affecting Hedonic Brand Loyalty on the Fine Dining Indonesian Food Restaurant in Jakarta

Kotler, P. (1973), “Atmospherics as a marketing tool”, Journal of Retailing, Vol. 49 No. 4, pp. 48-64.

Kwun, D.J.W. and Oh, H. (2006), "Past experience and self-image in fine dining intentions”, Journal of Foodservice Business Research, Vol. 9 No. 4, pp. 3-23.

Kwang-Ho Ahn, Minsung Kim \& Won-Moo Hur, (2011) "Building brand loyalty through managing brand community commitment", Management Decision, Vol. 49 Issue: 7, pp.1194-1213, https://doi.org /10.1108/00251741111151217

Ladhari, R. (2007) The Effect of Consumption Emotions on Satisfaction and Word-of-Mouth Communications. Psychology \& Marketing, 12, 1085-1108.

Lai, F., Griffin, M. and Babin, B.J. (2009), "How quality, value, image, and satisfaction create loyalty at a Chinese telecom", Journal of Business Research, Vol. 62 No. 10, pp. 9806.

Lee,J.H. and Hwang, J. (2011), "Luxury marketing: the influences of psychological and demographic characteristics on attitudes toward luxury restaurants", International Journal of Hospitality Management, Vol. 30 No. 3, pp. 658-669.

Liu, Y. and Jang, S.(S.) (2009), "The effects of dining atmospherics: an extended Mehrabian-Russell model", International Journal of Hospitality Management, Vol. 28 No. 4, pp. 494-503.

Lin, L.-Y. and Zhen, J.-H. (2005), "Extrinsic product performance signaling, product knowledge and customer satisfaction: an integrated analysis - an example of notebook consumer behavior in Taipei city", Fu Jen Management Review, Vol. 12 No. 1, pp. 65-91.

Lin, L.-Y. and Chen, C.-S. (2006), "The influence of the country-of-origin image, product knowledge and product involvement on consumer purchase decisions: an empirical study of insurance and catering services in Taiwan", Journal of Consumer Marketing, Vol. 23 No. 5, pp. 248-265.

Lee, M., \& L. Cunningham, F., "A cost/benefit approach to understanding service loyalty," Journal of Services Marketing, 15(2), 2001, pp. 113-130.

Lo, A., Wu, C. and Tsai, H. (2015), "The impact of service quality on positive consumption emotions in resort and hotel spa experiences", Journal of Hospitality Marketing \& Management, Vol. 24 No. 2, pp. 155-179.

Maguire L, Susi Geiger, (2015) "Emotional timescapes: the temporal perspective and consumption emotions in services", Journal of Services Marketing, Vol. 29 Issue: 3, pp.211-223, https://doi.org/10.1108/JSM02-2014-0047

Marks Larry J. and Jerry C. Olson (1981),"toward a Cognitive Structure Conceptualization of Product Familiarity", in NA - Advances in Consumer Research Volume 08, eds. Kent B. Monroe, Ann Abor, MI : Association for Consumer Research, Pages: 145-150.

Maxham, J.G., Netemeyer, R.G. (2002). Modeling customer perceptions of complaint handling over time: the effects of perceived justice on satisfaction and intent. Journal of Retailing, Vol.78, 239-252.

Mattila, A. S., \& Enz, C. A. (2002). The role of emotions in service encounters. Journal of Service Research, 4(4), 268-277

Nisco, A. and Warnaby, G. (2014), 'Urban design and tenant variety influences on consumers' emotions and approach behavior", Journal of Business Research, Vol. 67 No. 2, pp. 211-217.

Nguyen, N. and Leblanc, G. (2002), "Contact personnel, physical environment and the perceived corporate image of intangible services by new clients", International Journal of Service Industry Management, Vol. 13 No. 3, pp. 242-62.

American Research Journal of Business and Management

Page 20 
Factors Affecting Hedonic Brand Loyalty on the Fine Dining Indonesian Food Restaurant in Jakarta

Namkung, Y. and Jang, S. (2008), "Are highly satisfied restaurant customers really different? A quality perception perspective", International Journal of Contemporary Hospitality Management, Vol. 20 No. 2, pp. 142-155.

Namkung, Y., Jang, S.S., Almanza, B. and Ismail, J. (2009), "Identifying the underlying structure of perceived service fairness in restaurants", International Journal of Contemporary Hospitality Management, Vol. 21 No. 4, pp. 375-392.

Norman Peng, Annie Huiling Chen, (2015) "Diners' loyalty toward luxury restaurants: the moderating role of product knowledge”, Marketing Intelligence \& Planning, Vol. 33 Issue: 2, pp.179-196

Oliver (1997), Satisfaction: A Behavioral Perspective on the Consumer. New York: irwin/McGraw-Hill

Oliver, R.L. (1999), “Whence consumer loyalty?”, Journal of Marketing, Vol. 63 No. 4, pp. 33-44.

Ong, F.S., Khong, K.W., Faziharudean, T.M. and Dai, X. (2012), "Path analysis of atmospherics \& convenience on flow: the mediation effect of brand affect and brand trust", TheInternational Review of Retail, Distribution and Consumer Research, Vol. 22 No. 3,pp. 277-292.

Park, C. (2004), "Efficient or enjoyable? Consumer values of eating-out and fast food restaurant consumption in Korea”, International Journal of Hospitality Management, Vol. 23 No. 1, pp. 87-94.

Park c. whan v \& parker lessig," familiarity and its impact on consumer decision biases and heuristics" journal of consumer research ,vol. 8 , september 1981

Paswan, A.K., Spears, N., Hasty, R., and Ganesh, G. (2004). Search quality in the financial services industry: a contingency perspective. Journal of Services Marketing, 18(5), 324-338.

Patterson, P.G. and Spreng, R.A. (1997), "Modeling the relationship between perceived value, satisfaction and repurchase intentions in a business-to-business, services context: an empirical examination", International Journal of Service Industry Management, Vol. 8 No. 5, pp. 414-34.

Putri,P.I.,Aprianti,A and Septiandi,R (2016)"Pengaruh kualitas pelayanan terhadap brand loyalty (studi pada indihome PT. Telkom Indonesia, tbk di kota bandung", e-Proceeding of Management : Vol.3, No.3 December, ISSN : 2355-9357,p. Page 3771.

Prendergast, G. and Man, H.W. (2002), "The influence of store image on store loyalty in Hong Kong's quick service restaurant industry", Journal of Foodservice Business Research,Vol. 5 No. 1, pp. 45-59.

Quester, P., A. Al. Lim 2003. Product involvement/brand loyalty: Is there a link? Journal of Product \& Brand Management 12, no. 1: 22-38.

Rahmatika,I and Yuliviona,R (2014)," The Influence of service quality, store atmosphere on customer loyalty in enhai café with satisfaction as an intervening variable"Department of Management, Faculty of Economics, University of Bung Hatta.

Reza Dabestani, Arash Shahin, Mohammad Saljoughian, (2017) "Evaluation and prioritization of service quality dimensions based on gap analysis with analytic network process", International Journal of Quality \& Reliability Management, Vol. 34 Issue: 4, pp.530-548, https://doi.org/10.1108/IJQRM-042015-0050

Rudell, F., 1979. Consumer Food Selection and Nutrition Information. Praeger, New York.

Ruzica Brečić, Željka Mesić, Marija Cerjak, (2017) “Importance of intrinsic and extrinsic quality food characteristics by different consumer segments", British Food Journal, Vol. 119 Issue: 4, pp.845862, https://doi.org/10.1108/BFJ-06-2016-0284 
Ryu, K., Han, H. and Jang, S. (2010), "Relationships among hedonic and utilitarian values,satisfaction and behavioural intentions in the fast-casual restaurant industry", International Journal of Contemporary Hospitality Management, Vol. 22 No. 3, pp. 416-432.

Ryu, K., Han, H. and Jang, S. (2010), "Relationships among hedonic and utilitarian values, satisfaction and behavioral intentions in the fast-casual restaurant industry", International Journal of Contemporary Hospitality Management, Vol. 22 No. 3, pp. 416-432.

Ryu, K. and Jang, S.S. (2008), "Influence of restaurants' physical environments on emotion and behavioral intention”, The Service Industries Journal, Vol. 28 No. 8, pp. 1151-1165.

Ryu, K. and Han, H. (2010), "Influence of the quality of food, service, and physical environment on customer satisfaction and behavioral intention in quick-casual restaurants: moderating role of perceived price", Journal of Hospitality and Tourism Research, Vol. 34 No. 3, pp.310-329.

Ryu, K. and Han, H. (2011), "The influence of physical environments on disconfirmation, customer satisfaction, and customer loyalty for first-time and repeat customers in upscale restaurants", International Journal of Hospitality Management, Vol. 30 No. 3, pp. 599-611.

Ryu, K., Lee, H.R. and Kim, G. (2012), "The influence of the quality of the physical environment, food, and service on restaurant image, customer perceived value, customer satisfaction, and behavioral intentions", International Journal of Contemporary Hospitality Management,Vol. 24 No. 2, pp. 200-223.

Sekaran, U. and Bougie, R. (2009) Research Methods for Business: A Skill-Building Approach. 5th Edition, John Wiley and Sons Inc., Hoboken

Shaw, G., Bailey, A. and Williams, A. (2011), "Aspects of service-dominant logic and its implications for tourism management: examples for the hotel industry", Tourism Management, Vol. 32 No. 2, pp. 207-214.

Su, L., Swanson, S. and Chen, X. (2015), "The impact of perceived service quality and quality on the behavioral intentions of Chinese hotel guests: the mediating role of consumption emotions",Journal of Travel \& Tourism Marketing, Vol. 33 No. S1, doi: 10.1080/10548408.2015.1008668.

Tai, S.H.C. and Fung, A.M.C. (1997), "Application of an environmental psychology model toin-store buying behaviour", The International Review of Retail, Distribution and Consumer Research, Vol. 7 No. 4, pp. 311337.

Tsai, S.-P. (2014), "Love and satisfaction drive persistent stickiness: investigating international tourist hotel brands", International Journal of Tourism Research, Vol. 16 No. 6, pp. 565-577.

Uma, Sekaran. 2000. Research Methods for business: A Skill Building Approach. Singapore: John Wiley \& Sons, Inc.

Wang, C. C., dan Hwang, I. S. (2001). The Influence of Product Knowledge on the Amount of Merchandises Information Search on Internet. Journal of Business Administration, 51, pp. 109-138.

Wu, C.H.J. and Liang, R.D. (2009), "Effect of experiential value on customer satisfaction with service encounters in luxury-hotel restaurants", International Journal of Hospitality Management, Vol. 28 No. 4, pp. 586-593.

Wong, I.A. and Dioko, L(D)A.N. (2013), "Understanding the mediated moderating role of customer expectations in the customer satisfaction model: the case of casinos", TourismManagement, Vol. 36, pp. 188-199. 
Factors Affecting Hedonic Brand Loyalty on the Fine Dining Indonesian Food Restaurant in Jakarta

Yoon, Y. and Uysal, M. (2005), "An examination of the effects of motivation and satisfaction on dictation loyalty: a structural model", Tourism Management, Vol. 26 No. 1, pp. 45-56.

Zhu, P.-T. (2004), "The relationship among community identification, community trust, and purchase behaviorthe case of RVs communities", Masters degree thesis, Graduate School of International Business, National Dong Hwa University, Shoufeng.

Citation: Linda Desafitri R.B, Farida Jasfar, Hamdy Hady. "Factors Affecting Hedonic Brand Loyalty on the Fine Dining Indonesian Food Restaurant in Jakarta" American Research Journal of Business and Management. 2018; 4(1): 1-23.

Copyright (c) 2018 Linda Desafitri R.B, Farida Jasfar, Hamdy Hady. This is an open access article distributed under the Creative Commons Attribution License, which permits unrestricted use, distribution, and reproduction in any medium, provided the original work is properly cited. 